\title{
SECTORAL AND TERRITORIAL CHANGES IN THE ECONOMY OF THE STALINGRAD REGION IN 1940-1943
}

\author{
Vladimir A. Alyaev \\ Volgograd State University, Volgograd, Russian Federation
}

\author{
Mikhail V. Alyaev \\ Volgograd Cooperative Institute - Branch of Russian University of Cooperation, \\ Volgograd, Russian Federation
}

\begin{abstract}
The paper deals with historical, economic and geographical features of sectoral and territorial consequences of the impact of military actions on the national economy in the Stalingrad region. The authors consider approaches to the management of the economy of the RSFSR in the prewar and postwar periods, their peculiarities and differences. The elements of monitoring the accounting of destruction caused by the military actions in sectoral and territorial aspects are identified. The use of archival sources, including the archives introduced into academic circulation for the first time, allows to investigate the reduction in the most important indicators of industrial production and agriculture of the region for the period of 1940-1943.

In particular, the dynamics of production volumes at the industrial sites of the region, the number of people employed in the industry with specific companies during 1941-1943 were studied.

The special attention is paid to such key parameters of agricultural production as acreage, the number of working and productive livestock. Territorial differences in the changes of agricultural production in administrative districts in 1940-1946 are identified. The effect of mobilization of men and equipment to the agricultural productivity is studied. Based on statistical reports, the extent of damage to educational institutions and health care is determined. The main indicators of socio-economic status of urban and rural population in comparison with the prewar period (taking into account monetary and natural income residents of the region) are analyzed.

Special attention is also paid to the study of the impact of military operations on the railway and vehicular transport infrastructure, which had played a key role in the Victory of the Soviet troops at Stalingrad and in the postwar reconstruction of the national economy.

Key words: Great Patriotic War, Stalingrad Battle, postwar recovery of the national economy, industry, agriculture.

Citation. Alyaev V.A., Alyaev M.V. Sectoral and Territorial Changes in the Economy of the Stalingrad Region in 1940-1943. Vestnik Volgogradskogo gosudarstvennogo universiteta. Seriya 4, Istoriya. Regionovedenie. Mezhdunarodnye otnosheniya [Science Journal of Volgograd State University. History. Area Studies. International Relations], 2018, vol. 23, no. 1, pp. 144-155. (in Russian). DOI: https://doi.org/10.15688/jvolsu4.2018.1.14
\end{abstract}

\section{ОТРАСЛЕВЫЕ И ТЕРРИТОРИАЛЬНЫЕ ИЗМЕНЕНИЯ В ХОЗЯЙСТВЕ СТАЛИНГРАДСКОЙ ОБЛАСТИ ЗА 1940-1943 ГОДЫ}

\author{
Владимир Алексеевич Аляев
}

Волгоградский государственный университет, г. Волгоград, Российская Федерация

\section{Михаил Владимирович Аляев}

Волгоградский кооперативный институт (филиал) Российского университета кооперации, г. Волгоград, Российская Федерация 
Аннотация. В статье рассматриваются исторические и экономико-географические особенности отраслевых и территориальных последствий влияния военных действий на народное хозяйство Сталинградской области. Авторами были рассмотрены подходы к управлению экономикой РСФСР в предвоенный и послевоенный периоды, их особенности и различия. Выявлены элементы управления процессами учета разрушений от военных действий в отраслевом и территориальном аспектах. С привлечением архивных источников, в том числе вводимых в научный оборот впервые, были исследованы масштабы снижения важнейших показателей промышленного производства и сельского хозяйства области за 1940-1943 годы.

В частности, в динамике были изучены объемы производства на промышленных объектах области, численность занятых в промышленности за 1941-1943 гг. с указанием конкретных предприятий.

Детально рассматривались такие ключевые параметры аграрного производства, как посевные площади, поголовье рабочего и продуктивного скота. Были определены территориальные различия изменений сельскохозяйственного производства по административным районам области за 1940-1946 годы. Изучалось влияние мобилизации мужчин и техники на производительность сельского хозяйства. С опорой на статистические отчеты были определены масштабы ущерба учреждениям образования и здравоохранения. Анализировались основные показатели социально-экономического положения городского и сельского населения в сравнении с довоенным периодом (при этом учитывались как денежные, так и натуральные доходы жителей региона).

Особое внимание в работе уделено исследованию влияния военных действий на железнодорожную и автогужевую транспортную инфраструктуру, которые сыграли ключевую роль как в победе советских войск под Сталинградом, так и в послевоенном восстановлении народного хозяйства.

Аляев Владимир Алексеевич произвел поиск, выборку и анализ архивных материалов из фондов Государственного архива Волгоградской области о демографических процессах, состоянии аграрного и промышленного секторов экономики Сталинградской области в изучаемый период. Аляев Михаил Владимирович осуществил поездку в Самарский филиал Российского государственного архива научно-технической документации (РГАНТД) и произвел поиск, выборку и анализ архивных материалов о состоянии транспортной инфраструктуры Сталинградской области в изучаемый период, а также редактирование текста.

Ключевые слова: Великая Отечественная война, Сталинградская битва, послевоенное восстановление народного хозяйства, промышленность, сельское хозяйство.

Цитирование. Аляев В. А., Аляев М. В. Отраслевые и территориальные изменения в хозяйстве Сталинградской области за 1940-1943 годы // Вестник Волгоградского государственного университета. Серия 4, История. Регионоведение. Международные отношения. - 2018. - Т. 23, № 1. - С. 144-155. - DOI: https:// doi.org/10.15688/jvolsu4.2018.1.14

Военные действия в период Сталинградской битвы характеризовались большим ожесточением. Она оказали большое разрушающее воздействие на мирное хозяйство области. Центральные органы управления страной учитывали эти процессы. Еще в 1938 г. в структуре Госплана был создан институт уполномоченных, которые были обязаны на местах организовывать проверки выполнения плана, следить за соблюдением пропорций между отраслями специализации, вспомогательными отраслями и сферой услуг в экономическом районе. Осенью 1942 г. уполномоченные Госплана были назначены в каждой области страны [11, с. 195]. Им были подчинены местные управления статистики. Работа уполномоченных в тот период времени была направлена на выявление отраслевых и территориальных последствий военных действий. Согласованная работа центральных и региональных органов управления позволила сфор- мировать объективную информационную базу. Именно эти наработки и легли в основу экономического анализа потерь области, понесенных в годы Великой Отечественной войны.

Государственная программа восстановления народного хозяйства на временно оккупированных территориях предполагала упорядоченную систематизированную последовательность в налаживании экономики. В области был разработан план восстановления мирного хозяйства. Его важной составной частью была оценка уровня потерь и разрушений по сравнению с предвоенными годами. В документах того периода времени можно изучить степень снижения объемов производства, последовавшего после разрушений в период Сталинградской битвы. В 1941 г. союзная и республиканская промышленность Сталинградской области выпустила продукции больше, чем в 1940 году. К примеру, завод «Красный Октябрь» на 12,7 \%, завод № 91 - на 15,6 \%. 
Снижение объемов валовой продукции крупнейших предприятий Сталинградской области в 1943 г. по сравнению с 1941 г. представлено в таблице 1.

Данные таблицы показывают, что на всех предприятиях, ранее определявших специализацию области в рамках всей страны, произошло обвальное снижение объемов производства. В то же время на заводе «Красный Октябрь», в цехах которого шли ожесточенные бои, уже в 1943 г. возобновили производство металла. Особенно пострадали предприятия, располагавшиеся в зоне боев - Сталинградский тракторный завод, завод «Баррикады», лесозавод им. Куйбышева, завод силикатного кирпича и ряд городских хлебозаводов. В натуральном выражении производство стали и проката на заводе «Красный Октябрь» в 1943 г. составило 22,0 тыс. т и 18,0 тыс. т соответственно. Для сравнения в 1938 г. завод произвел 744,6 тыс. т мартеновской стали и 550,9 тыс. т проката [3, л. 14, 49]. В г. Сталинграде резко снизилось число занятых на промышленных предприятиях. Если в 1941 г. на «Красном Октябре» работало 12272 человека, то в 1943 г. - всего 1370 человек. Соответствующие показатели на Сталинградском тракторном заводе составили 23076 человек и 2240 человек соответственно, на заводе «Баррикады» 19328 человек и 680 человек соответственно, на заводе им. Кирова - 2121 человек и 484 человека соответственно [13, л. 39-40].

Огромный урон был нанесен сельским территориям области. Он обусловил возникновение ряда проблем. Кроме снижения чис- ленности населения, особенно мужчин в молодом возрасте, произошло снижение уровня механизации сельскохозяйственного производства. Если на 1 января 1940 г. в области насчитывалось 18,8 тыс. тракторов, то на 1 января 1944 г. - 14,2 тыс. тракторов, что на 24,5 \% меньше. За этот же период число комбайнов уменьшилось с 6,9 тыс. шт. до 4,7 тыс. шт., или на $31,9 \%$ [8, л. 80]. Снижение трудовой обеспеченности и степени механизации в растениеводстве обусловили уменьшение посевных площадей, валового сбора зерновых культур, а также их урожайности. Подробные данные представлены в таблицах 2, 3, 4.

Данные таблиц свидетельствуют о больших изменениях в базовой отрасли сельского хозяйства - растениеводстве. Валовой сбор зерна снизился на $93,7 \%$, урожайность - на 74,0 \%, посевные площади - на 43,8 \%. Разрушение растениеводства обусловило негативные явления и животноводстве, а также в социально-экономическом положении населения области.

На изменения поголовья рабочего и продуктивного скота, кроме уже названного снижения кормовой базы, сказалось использование лошадей для перевозок в армии. Кроме того, животноводство отличается от растениеводства значительно большими затратами ручного труда. Следовательно, на динамику поголовья повлияло и снижение трудовых ресурсов. Сильно сказалась и временная оккупация, когда захватчики забирали скот и птицу. Динамика поголовья скота представлена в таблице 5.

\section{Валовая продукция крупнейших предприятий Сталинградской области} в 1941-1943 гг., тыс. руб.

\begin{tabular}{|l|r|r|c|}
\hline \multicolumn{1}{|c|}{ Название предприятия } & 1941 г. & 1943 г. & $\begin{array}{c}1943 \text { г. по отношению } \\
\text { к 1941 г., \% }\end{array}$ \\
\hline Завод «Красный Октябрь» & 246069 & 4000 & 1,60 \\
\hline Сталэнергокомбинат & 39786 & 3835 & 9,60 \\
\hline СТ3 & 660449 & - & - \\
\hline Завод № 264 (судостроительный) & 119767 & - & - \\
\hline Завод № 221(«Баррикады») & 552768 & - & 22,60 \\
\hline Завод № 91 (им. Кирова) & 44213 & 10000 & 5,60 \\
\hline Лесозавод им. Куйбышева & 17747 & 1000 & 37,50 \\
\hline Лесозавод № 7 & 1143 & 429 & 1,27 \\
\hline Завод силикатного кирпича & 1413 & 18 & 16,0 \\
\hline Росглавхлеб Сталинград & 26239 & 4186 & \\
\hline
\end{tabular}

Примечание. Составлено и рассчитано по данным: [2, л. 9-12]. 
B.А. Аляев, М.В. Аляев. Отраслевые и территориальные изменения в хозяйстве Сталинградской области

Посевные площади в колхозах Сталинградской области

Таблича 2

в 1940-1943 гг., тыс. га

\begin{tabular}{|c|c|c|c|c|}
\hline 1940 г. & 1941 г. & 1942 г. & 1943 г. & $\begin{array}{c}1943 \text { г. } \\
\text { по отношению } \\
\text { к 1940 г., \% }\end{array}$ \\
\hline 3426 & 3348 & 2278,00 & 1926,30 & 56,20 \\
\hline
\end{tabular}

Примечание. Составлено и рассчитано по данным: [20, л. 1а].

Таблица 3

Валовый сбор зерновых культур в колхозах Сталинградской области в 1940-1943 гг., тыс. т

\begin{tabular}{|c|c|c|c|c|}
\hline 1940 г. & 1941 г. & 1942 г. & 1943 г. & $\begin{array}{c}1943 \text { г. } \\
\text { по отношению } \\
\text { к } 1940 \text { г., } \%\end{array}$ \\
\hline 2640,0 & 1627,4 & 524,0 & 167,5 & 6,3 \\
\hline
\end{tabular}

Примечание. Составлено и рассчитано по данным: [20, л. 1а].

Таблица 4

Урожайность зерновых культур в колхозах Сталинградской области в 1940-1943 гг., ц/га

\begin{tabular}{|c|c|c|c|c|}
\hline 1940 г. & 1941 г. & 1942 г. & 1943 г. & $\begin{array}{c}1943 \text { г. } \\
\text { по отношению } \\
\text { к 1940 г., \% }\end{array}$ \\
\hline 9,6 & 9,3 & нет св. & 2,5 & 26,0 \\
\hline
\end{tabular}

Примечание. Составлено и рассчитано по данным: [20, л. 1a].

Таблица 5

Поголовье рабочего и продуктивного скота, птицы и кроликов в колхозах Сталинградской области в 1940-1943 гг., тыс. голов

\begin{tabular}{|l|c|c|c|c|c|}
\hline \multicolumn{1}{|c|}{ Название } & 1940 г. & 1941 г. & 1942 г. & 1943 г. & $\begin{array}{c}1943 \text { г. } \\
\text { по отношению } \\
\text { к 1940 г., \% }\end{array}$ \\
\hline Лошади & 179,6 & 173,6 & 117,4 & 84,6 & 47,1 \\
\hline $\begin{array}{l}\text { Крупный рогатый } \\
\text { скот, всего }\end{array}$ & 451,4 & 460,8 & 239,4 & 237,0 & 52,5 \\
\hline $\begin{array}{l}\text { В том числе } \\
\text { коровы }\end{array}$ & 90,5 & 104,5 & 61,2 & 47,5 & 52,5 \\
\hline Свиньи & 134,6 & 154,2 & 57,0 & 25,0 & 18,6 \\
\hline Верблюды & 12,5 & 11,7 & 6,3 & 7,5 & 60,0 \\
\hline Птица & 529,0 & нет св. & нет св. & 300,0 & 56,7 \\
\hline Кролики & нет св. & нет св. & 69,0 & 15,0 & 21,7 \\
\hline Овцы и козы & 1152 & 1365 & 576,4 & 513,0 & 44,5 \\
\hline
\end{tabular}

Примечание. Составлено и рассчитано по данным: [21, л. 13].

Анализ данных таблицы 5 показывает, что в целом животноводство сократилось примерно наполовину. Особенно резкий спад произошел в поголовье свиней, которое в значительной степени ориентируется на концентрированные корма. Тяжелые последствия для питания населения имело уменьшение поголовья коров. Ущерб, нанесенный сельскому хозяйству области захватчиками, породил колоссальные социально-экономические проблемы среди населения.
На фоне снижения числа участвующих в колхозном производстве с 480,5 тыс. человек (в 1941 г.) до 347,1 тыс. человек (в 1943 г.) сельское население увеличило участие в общественном труде [10, л. 14]. Если в 1941 г. в колхозном производстве участвовало $63 \%$ трудоспособных, то в 1943 г. - $72 \%$. При этом снизилась доля престарелых и нетрудоспособных с $22 \%$ в 1941 г. до 11,6 \% в 1943 г., но возросла доля подростков от 12 до 16 лет с $14 \%$ до 16,2 \%. Изменения возрастной струк- 
туры населения в области были схожи с показателями по всей стране. Они во многом объясняются ростом уровня смертности населения тыловых районов страны. В частности, в январе 1942 г. уровень смертности превысил показатели соответствующего месяца 1941 г. на 43,1 \%, в феврале 1942 г. - на 52,7 \%, в марте - на $65,5 \%$ [18, с. 283]. Рост смертности происходил из-за изменившихся в худшую сторону условий жизни гражданского населения.

Изменения в половозрастной структуре работавшего в колхозах населения и потери в уровне механизации обусловили снижение производительности труда. Если 1941 г. не имели трудодней $1,2 \%$ колхозников и не выработали трудовой минимум $6,9 \%$ колхозников, то в 1943 г. эти показатели составили соответственно $0,5 \%$ и $11,3 \%$. Снизилось число колхозников с самой высокой производительностью труда (более 400 трудодней) с 15,4\% в 1941 г. до 9,4 \% в 1943 году. Одновременно выросла доля колхозников с выработкой от 100 до 200 трудодней с $23,7 \%$ до $32,0 \%$ у взрослых и с 13,7 \% до 18,4 \% у подростков.

Снижение производительности труда, изменения в распределении продукции сельского хозяйства вызвали перемены в выдаче колхозникам на трудодни зерновых и зернобобовых культур [9, л. 8]. В урожайном 1941 г. 115,5 тыс. человек (24 \% от всех участвовавших в производстве с выработкой 300-400 трудодней) получали 700-800 кг зерна, а 193,3 тыс. человек (40,3 \% с выработкой 100 300 трудодней) - по 300-500 кг зерна. В 1943 г. группа колхозников с высокой производительностью труда составила 59,5 тыс. человек $(17,1 \%)$, и они получали на трудодни от 91 кг до 104 кг зерна. Группа с выработкой 100300 трудодней составляла 164,4 тыс. человек $(47,3 \%)$, и они получали от 39 кг до 65 кг зерна. В среднем выдача зерна на 1 трудодень в 1943 г. составила $13 \%$ от уровня 1941 года.

Важную роль в обеспечении сельского населения выполняли денежные доходы колхозников [17, л. 11]. В 1941 г. колхозы получили доходы в сумме 269,2 млн рублей. Из них на трудодни было направлено 99,8 млн рублей, или $35,7 \%$. В среднем на одного участвовавшего в производстве приходилось 208,1 рублей. В 1943 г. сумма денежных доходов колхозов снизилась до 165,9 млн руб. и составила $61,6 \%$ от уровня 1941 года. На денежную оплату трудодней было выделено 18,6 млн руб., или $11,3 \%$ от всех доходов. На одного работавшего в производстве приходилось 53,6 руб. - 25,7 \% от уровня 1941 года.

Колхозное производство помимо функций обеспечения населения средствами существования решало и другие задачи. В 1941 г. 56,4 \% валового сбора зерновых культур было направлено на обязательные поставки натуроплаты и возврат ссуд; $14,2 \%$ - в семенной фонд; $1,1 \%$ продано государственным заготовительным органам; 0,97 \% продано на колхозном рынке; $8,9 \%$ отчислено в прочие фонды [1, л. 10]. Близкая структура распределения валового сбора зерновых культур наблюдалась и в 1943 году. Развязанная фашистами война, военные действия на территории Сталинградской области затормозили развитие сельского хозяйства. Территориальные различия изменений сельскохозяйственного производства по административным районам представлены в таблице 6.

Анализ данных таблицы 6 позволяет говорить о порайонных различиях в основных отраслях сельского хозяйства области. В целом по области повсеместно произошло снижение посевных площадей, при этом в 26 районах высокое снижение. В этой группе выделяются районы, на территории которых происходили ожесточенные боевые действия, - Верхне-Курмоярский, Ворошиловский, Городищенский, Калачевский, Красноармейский, Тормосиновский. Среднее снижение произошло в 29 районах, и относительно низкое снижение посевных площадей - в 7 районах. Там, где шли ожесточенные бои вначале по обороне подступов к г. Сталинграду, а затем по окружению врага, сельскому хозяйству был нанесен наибольший урон. Относительно небольшое снижение доли посевных площадей в Кагановичском и Чернышковском районах можно объяснить тем, что их территории не попали в зону ожесточенных боевых действий. Отметим, что в среднем по стране за аналогичный период посевные площади снизились до 75,5 \% [5, с. 259].

Архивные данные свидетельствуют о том, что огромный ущерб был нанесен таким социально значимым отраслям экономики, как образование и здравоохранение. 
В.А. Аляев, М.В. Аляев. Отраслевые и территориальные изменения в хозяйстве Сталинградской области

Изменения посевных площадей по колхозам сельских районов Сталинградской области

\begin{tabular}{|c|c|c|c|c|}
\hline \multirow[b]{2}{*}{$\begin{array}{c}\text { № } \\
\Pi / \Pi\end{array}$} & \multirow[b]{2}{*}{ Наименование районов } & \multicolumn{3}{|c|}{ Посевные площади, тыс. га } \\
\hline & & 1940 г. & 1946 г. & $\begin{array}{c}1946 \text { г. } \\
\text { по отношению } \\
\text { к } 1940 \text { г., \% }\end{array}$ \\
\hline 1 & Алексеевский & 63,3 & 34,8 & 55,0 \\
\hline 2 & Балыклейский & 61,5 & 29,1 & 47,3 \\
\hline 3 & Березовский & 55,5 & 30,3 & 54,6 \\
\hline 4 & Бударинский & 49 & 28,1 & 57,3 \\
\hline 5 & Быковский & 43 & 22,1 & 51,4 \\
\hline 6 & Верхне-Курмоярский & 55,9 & 26,1 & 46,7 \\
\hline 7 & Ворошиловский & 89,3 & 37,6 & 42,1 \\
\hline 8 & Вязовский & 66,1 & 35,7 & 54 \\
\hline 9 & Гмелинский & 12,8 & 10,5 & 82,0 \\
\hline 10 & Городищенский & 55,4 & 24,7 & 44,6 \\
\hline 11 & Даниловский & 63,5 & 32,4 & 51,0 \\
\hline 12 & Добринский & 40,5 & 27,3 & 67,5 \\
\hline 13 & Дубовский & 63,7 & 28,8 & 45,2 \\
\hline 14 & Еланский & 71,4 & 43,3 & 60,6 \\
\hline 15 & Ждановский & 56,1 & 27,7 & 49,4 \\
\hline 16 & Иловатский & 33,8 & 21 & 62,1 \\
\hline 17 & Иловлинский & 48,2 & 27,2 & 56,4 \\
\hline 18 & Кагановичский & 66,7 & 42,3 & 63,4 \\
\hline 19 & Кайсацкий & 33,4 & 16,2 & 48,4 \\
\hline 20 & Калачевский & 84,1 & 37,8 & 45 \\
\hline 21 & Калининский & 58,7 & 34,8 & 59,3 \\
\hline 22 & Камышинский & 62,7 & 40 & 63,8 \\
\hline 23 & Киквидзенский & 48,5 & 30,6 & 63,1 \\
\hline 24 & Клетский & 74,6 & 40 & 53,6 \\
\hline 25 & Комсомольский & 54,3 & 26,1 & 48,1 \\
\hline 26 & Котельниковский & 56,4 & 29,5 & 52,3 \\
\hline 27 & Красноармейский & 40,6 & 15,3 & 37,7 \\
\hline 28 & Краснослободский & 3,1 & 2,7 & 87,0 \\
\hline 29 & Кругловский & 66,4 & 31,8 & 47,9 \\
\hline 30 & Кумылженский & 41,9 & 28,7 & 68,5 \\
\hline 31 & Лемешкинский & 66,6 & 43,4 & 65,2 \\
\hline 32 & Ленинский & 37,1 & 29,7 & 80 \\
\hline 33 & Логовский & 31,4 & 22,3 & 71,0 \\
\hline 34 & Мачешанский & 63,2 & 32,3 & 51,1 \\
\hline 35 & Медведицкий & 38,3 & 24,8 & 64,7 \\
\hline 36 & Михайловский & 58,6 & 34,4 & 58,7 \\
\hline 37 & Молотовский & 40,7 & 30,6 & 75,3 \\
\hline 38 & Неткачевский & 58,7 & 33,8 & 57,6 \\
\hline 39 & Нехаевский & 56,9 & 36,7 & 64,4 \\
\hline 40 & Нижне-Добринский & нет св. & нет св. & нет св. \\
\hline 41 & Нижне-Чирский & 70 & 38,6 & 55,1 \\
\hline 42 & Николаевский & 70,4 & 38,4 & 54,5 \\
\hline 43 & Новоаннинский & 56,5 & 44,9 & 79,5 \\
\hline 44 & Новониколаевский & 60,4 & 39,4 & 65,2 \\
\hline 45 & Ольх овский & 76,3 & 31 & 40,6 \\
\hline 46 & Палласовский & 16,1 & 9,2 & 57,1 \\
\hline 47 & Перелазовский & 55,5 & 28,5 & 51,4 \\
\hline 48 & Подтелковский & 45,8 & 22,2 & 48,6 \\
\hline 49 & Пролейский & 54,7 & 24,9 & 45,5 \\
\hline 50 & Раковский & 42 & 22 & 52,4 \\
\hline 51 & Ремениковский & нет св. & нет св. & нет св. \\
\hline
\end{tabular}


Окончание таблицьь 6

\begin{tabular}{|c|c|c|c|c|}
\hline \multirow[b]{2}{*}{$\begin{array}{c}\text { № } \\
\Pi / \Pi\end{array}$} & \multirow[b]{2}{*}{ Наименование районов } & \multicolumn{3}{|c|}{ Посевные площади, тыс. га } \\
\hline & & 1940 г. & 1946 г. & $\begin{array}{c}1946 \text { г. } \\
\text { по отношению } \\
\text { к } 1940 \text { г., \% }\end{array}$ \\
\hline 52 & Руднянский & 66,7 & 44,1 & 66,1 \\
\hline 53 & Серафимовичский & 53,7 & 25,7 & 47,8 \\
\hline 54 & Сиротинский & 31,8 & 17,6 & 55,3 \\
\hline 55 & Солодчинский & 56,1 & 31,3 & 55,8 \\
\hline 56 & Среднеахтубинский & 35,3 & 24,6 & 69,7 \\
\hline 57 & Старополтавский & 42,7 & 23,4 & 54,8 \\
\hline 58 & Тормосиновский & 37,6 & 17,3 & 46,0 \\
\hline 59 & Урюпинский & 50 & 35,4 & 70,8 \\
\hline 60 & Фроловский & 47,5 & 24,4 & 51,4 \\
\hline 61 & Фрунзенский & 43,2 & 26,6 & 61,6 \\
\hline 62 & Хоперский & 39,4 & 27,3 & 69,3 \\
\hline 63 & Чернышковский & 44,3 & 32,5 & 73,4 \\
\hline 64 & Эльтонский & 82,9 & 47,2 & 56,9 \\
\hline & Итого по области & 3250,8 & 1827 & 56,0 \\
\hline
\end{tabular}

Примечание. Составлено и рассчитано по данным: [12, л. 2-4].

Сеть общеобразовательных школ того периода была представлена начальными, неполными средними и средними школами. С 1940 г. по 1942 г. в ней произошли значительные негативные изменения [19, л. 90-92]. Общее число школ в области сократилось на 271 единицу (или на 12,1\%). При этом значительная доля снижения числа школ пришлась на средние школы (соответственно, на 50 школ, или 76,1%). Значительно уменьшилось число всех учащихся - с 406,1 тыс. человек в 1940 г. до 200,8 тыс. человек в 1942 г., или на 50,6 \%. Число учащихся начальных классов уменьшилось на 45,0 \%, 5-7 классов - на 57,2 \%, а 8-10 классов - на 59,5\%. В 1942 г. не функционировала сеть школ для взрослых, а в 1940 г. в ней обучалось 9000 человек. Резко уменьшилась сеть дошкольного образования. Число детских садов снизилось со 114 единиц в 1940 г. до 79 единиц в 1942 г. (на $30,7 \%$ ). Сеть детских домов уменьшилась на 77,4 \%, а число детей в них с 3196 в 1940 г. до 963 человек в 1942 г. (на 69,9\%). Указанные тенденции напрямую связаны с разрушением зданий образовательных учреждений в ходе военных действий, так как в них зачастую располагались госпитали, штабы воинских подразделений. Кроме того, строительные материалы, из которых были построены образовательные учреждения, использовались для возведения фортификационных сооружений.
Учреждения здравоохранения также перенесли значительные изменения [16, л. 98101]. Число больниц уменьшилось с 203 единиц до 164 единиц, или на 19,1\%. Число больничных коек в 1942 г. составило 44,4 \% от уровня 1944 года. При этом были сохранены родильные дома. Значительно уменьшилось число больничных коек в психиатрических учреждениях - на 44,1 \%. Число мест в детских яслях сократилось с 12313 мест до 5101 места, или на 55,6\%.

Изменения в сети учреждений образования и здравоохранения объясняются тем, что на временно оккупированных территориях местные жители изгонялись из жилых домов в погреба или землянки, а захватчики занимали для размещения наиболее комфортные места. Здания школ, больниц разрушались для использования материалов при строительстве фортификационных сооружений.

Огромные разрушения наблюдались в транспортной инфраструктуре. Сталинградский регион, через территорию которого проходили важнейшие для страны железнодорожные магистрали, попал в зону влияния масштабных работ по восстановлению железных дорог. Это особенно наглядно проявляется в материалах по восстановлению линии Сталинград - Тихорецкая [7, л. 3]. Эта работа была выполнена сотрудниками проектного института при Министерстве путей сообщения. Ее анализ представляет большой интерес, ибо в 
таких работах отражались новые подходы к управлению восстановлением и строительством масштабных объектов транспортной инфраструктуры.

Линия Сталинград - Тихорецкая включала в себя Сталинградский узел и линию Сарепта - Тихорецкая. В 1939 г. по линии было перевезено 4,4 млн т грузов, в том числе по прибытию 2,7 млн т, а по отправлению 1,7 млн т. Наибольший удельный вес в перевозимых грузах имел каменный уголь. Затем по убывающей следовали доли минерально-строительных грузов, в равной доле - хлебные и лесные грузы. Причем каменный уголь в подавляющей части прибывал на станции Сталинградского узла. Хлебные грузы имели преобладание отправления за счет участков Котельниково - Сальск, Сальск -Тихорецкая. Лесные грузы имели преобладание за счет участка Сталинград - Сарепта. Доля прибытия и отправления минерально-строительных материалов была почти равной, то есть их перевозка имела линейный характер. Из-за значительного объема перевозимых грузов линия имела категорию магистрали. Ее значимость резко возросла в годы Великой Отечественной войны. В условиях постоянных бомбардировок основного кавказского хода Миллерово - Воронеж линия стала наиболее коротким путем, связывающим районы Кавказа с центральными регионами страны. Кроме того, благодаря новостройкам Сталинград - Камышин, Сталинград - Владимировка через линию Сталинград - Тихорецкая появилась возможность сокращения путей восточных воинских эшелонов на 300 км [7, л. 5].

В предвоенный период линия имела достаточно высокий уровень комплексности железнодорожной транспортной инфраструктуры. Она была представлены 57 раздельными пунктами, в том числе 5 участковыми, 27 промежуточными станциями, 25 разъездами. Из них на 40 раздельных пунктах осуществлялись коммерческие операции. Соотношение длины ландшафтных путей к главному на линии составляло 0,5 (половину от его развернутой длины). На 1 км станционных путей приходилось 3,2 стрелочных перевода. На 1 раздельный пункт приходилось $913 \mathrm{~m}^{2}$ площади пакгаузов.

Наиболее развитой на линии была транспортная инфраструктура Сталинградского узла, где соотношение станционных путей к главному имело коэффициент 1,34. На 1 км станционных путей приходилось 6 стрелочных переводов, а на 1 раздельный пункт площадь пакгаузов составляла $1695 \mathrm{~m}^{2}[7$, л. 6].

В связи с разной степенью значимости Сталинградского узла и остальной части линии работы по выявлению и учету разрушений от военных действий проводились раздельно. На линиях Сталинградского узла было разрушено $27,7 \%$ пути, 42,2 \% стрелочных переводов, 67 \% водоподъемных сооружений. Оставшиеся на станциях узла 210 паровозов были повреждены осколками бомб и снарядов. Фактически все столбы линий связи на узле были снесены (3 260 шт.). Основными причинами разрушений были: а) повреждения от авиабомб и артснарядов; б) минирование; в) использование верхнего строения пути (рельсы, шпалы) на устройство дзотов и блиндажей.

На остальной части линии было разрушено 13,4 \% пути, 52,5 \% стрелочных переводов. При длине этого участка в 693 км объемы разрушений поражают масштабами. Здесь в отличие от станций узла противником проводились крупные заградительные работы (подрыв стыков в шахматном порядке, полный подрыв стрелочных переводов) [7, л. 4-30].

При рассмотрении остальных частей транспортной инфраструктуры было выявлено, что наибольшие разрушения имели следующие устройства: 1) мосты - на 54,5 \% в среднем (на отдельных участках до $92 \%$ ); 2) гидроколонки - на $86 \%$; 3 ) баки водяные на $62 \%$; 4) электростанции - на $100 \%$; 5) вагонные депо - на $100 \%$; 6) станционные здания - на 74 \%. Значительно меньше были разрушены устройства, углубленные в землю подземные резервуары нефтесмазочного хозяйства - на $11 \%$, разводящие и напорные сети на $0,35 \%$ ).

После окончания военных действий восстановление верхнего строения пути, связи и водоснабжения как элементов транспортной инфраструктуры, без которых невозможен процесс перевозки, производилось силами воинских формирований. Устройства других частей инфраструктуры восстанавливались силами работников дороги. К 8 апреля 1943 г. движение на станциях Сталинградского узла восстановлено. 
В результате проведения восстановительных работ по Сталинградскому узлу было восстановлено 23 тыс. м ${ }^{3}$ земельного полотна, уложено 2018 шт. рельсов, убрано 2,3 тыс. т металлолома, перемещено 3068 поврежденных вагонов [7, л. 33].

В то же время было выявлено, что значительные задержки в восстановлении линии Сталинград - Тихорецкая произошли из-за несвоевременного составления проектных работ, резких расхождений в восстановлении отдельных частей инфраструктуры. Ошибочной была признана ориентация на полный капитальный ремонт при восстановлении, ибо почти сразу же после его проведения были, в частности, бомбардировками полностью выведены из строя депо на станциях Глубокая, Чертково.

Как видно, сразу же после окончания военных действий в районе влияния Сталинградской битвы проводились научные исследования, результаты которых в последующем учитывались при развитии железнодорожной транспортной инфраструктуры. Кроме того, эта работа отчетливо показала, что транспортная инфраструктура является стратегически важной составной частью хозяйства региона.

Серьезное влияние оказали военные действия на автогужевую транспортную инфраструктуру, игравшую большую роль в выполнении местной транспортной работы. Архивные данные свидетельствуют о том, что в ходе военных действий, а также в результате немецко-фашистской оккупации в 14 районах региона было разрушено 52 км полотна шоссейных дорог, 70 автомобильных мостов протяженностью 2154 погонных метра, 46 грузовых автомобилей, 20 легковых автомобилей $[22$, л. 6]. Сильные разрушения материальнотехнической базы произошли в дорожном хозяйстве региона. Они обусловили фактически прекращение реконструкции местных дорог. В 1944 г. ее объем составил 1,1\% от уровня 1940 года. В то же время по сравнению с 1940 г. резко возросли объемы капитального ремонта дорог - 190 \% в 1943 году. На $241 \%$ возросли объемы капитального ремонта мостовых сооружений в 1943 г. по сравнению с 1940 г. [14, л. 138]. Семь мостов через р. Дон длиной 2120 погонных метров были восстановлены наступавшими частями наших войск
[6, л. 197]. Резко сократилось количество подвижного состава автотранспорта. Если в 1940 г. в регионе было 168 грузовых автомашин, то в 1943 г. сохранилось 19 грузовиков, или 11 \% [15, л. 133]. Как видно, автогужевая инфраструктура в условиях военных действий подверглась сильному разрушению. Высокие темпы восстановительных работ были обеспечены необходимостью решения военных задач.

Таким образом, согласованная работа центральных и местных органов управления способствовала получению объективных данных о состоянии мирного хозяйства области после военных действий. Наибольший урон был нанесен предприятиям отраслей специализации - заводу «Красный Октябрь», тракторному заводу, заводу № 221 («Баррикады»). Произошло резкое снижение посевных площадей в области, уменьшилась урожайность зерновых культур, сократилось поголовье рабочего и продуктивного скота. Военные действия изменили социально-экономическое состояние сельского населения. Из-за снижения производительности труда по причине мобилизации мужского населения и отзыва тракторов и автомобилей в действующую армию выдача зерна на трудодень в 1943 г. составила $13 \%$ от уровня 1941 года. Денежные доходы сельского населения в 1943 г. составили $25,7 \%$ от уровня 1941 года.

Изменились размеры посевных площадей в разрезе административных районов. В наибольшей степени они снизились в районах, находившихся в зоне военных действий 44,6 \% на 1946 г. от уровня 1940 г. в Городищенском районе. Уменьшилось число школ на $12,1 \%$, а число учащихся снизилось на $50,6 \%$. Число больниц уменьшилось на 19,1\%.

Огромные разрушения наблюдались в транспортной инфраструктуре. На станциях Сталинградского железнодорожного узла по лини Сталинград - Тихорецкая было разрушено 27,7 \% путей, 42,2 \% стрелочных переводов, 67 \% водоподъемных сооружений. Резко снизилось количество подвижного состава автотранспорта - на $89 \%$.

Таким образом, согласованная работа центральных и местных органов управления способствовала получению объективных данных о состоянии мирного хозяйства области после военных действий. Учитывались отраслевые 
особенности разрушений. При этом выделялись отрасли специализации, вспомогательные и обслуживающие отрасли. Важное значение имело выявление территориальных различий в последствиях военных действий. Как видно, экономико-географические подходы способствовали принятию в 1943 г. общегосударственной программы «О неотложных мерах по восстановлению хозяйства в районах, освобожденных от немецкой оккупации». Именно систематизированные статистические обследования мирного хозяйства способствовали разработке плана послевоенного восстановления хозяйства области, то есть сбор достоверных статистических данных о состоянии дел в отдельных отраслях народного хозяйства области и своевременная их отправка в союзный центр позволили составить стратегические программы восстановления экономики и получить оперативно соответствующие ресурсы.

\section{СПИСОК ЛИТЕРАТУРЫ}

1. Анализ распределения валового сбора зерновых и бобовых культур в колхозах области за 1941-1946 годы // Государственный архив Волгоградской области (далее-ГАВО). - Ф. 2085. -Оп. 6. Д. 13. -19 л.

2. Валовая продукция в неизменных ценах по предприятиям союзной и республиканской промышленности Сталинградской области за 19431947 годы // ГАВО. - Ф. 686. - Оп. 20. - Д. 5. - 152 л.

3. Валовая продукция в натуральном выражении // ГАВО. - Ф. 2085. - Оп. 1. - Д. 4. - 174 л.

4. Выпуск главных видов продукции союзной и республиканской промышленности Сталинградской области за 1943-1947 годы // ГАВО. Ф. 686. - Оп. 20. - Д. 5. - 152 л.

5. Гладков, И. А. Советская экономика в период Великой Отечественной войны 1941-1945 гг. / И. А. Гладков. - М. : Наука, 1970. - 505 с.

6. Доклад председателю СНК РСФСР Косыгину от 10 декабря 1943 года // ГАВО. - Ф. 2115. Оп. 1. - Д. 989. - 211 л.

7. Материалы по восстановлению линии Сталинград - Тихорецкая. 1943 г. // РГАНТД. Ф. Р-129. - Оп. 5-1. - Д. 166. - 88 л.

8. Механизация сельского хозяйства Сталинградской области на период 1944-1947 годов // ГАВО. - Ф. 686. - Оп. 20. - Д. 5. - 111 л.

9. О размере трудодня колхозников (натурой) за 1941-1946 годы // ГАВО. - Ф. 2085. - Оп. 6. Д. 13. - 19 л.
10. О трудовой дисциплине колхозников за 19411946 годы // ГАВО. - Ф. 2085. - Оп. 6. -Д. 13. - 19 л.

11. Планирование размещения производительных сил СССР. В 2 ч. Ч. 1. - М. : Экономика, 1985. $-304 \mathrm{c}$.

12. Посевные площади по районам Сталинградской области за 1940-1943 годы // ГАВО. Ф. 2085. - Оп. 1. - Д. 25. - 139 л.

13. Потребность рабочей силы для промышленных предприятий города Сталинграда на 19431947 годы // ГАВО. - Ф. 686. - Оп. 20. - Д. 5. - 81 л.

14. Пятилетний план восстановления и развития дорожного хозяйства Сталинградской области на 1946-1950 годы // ГАВО. - Ф. 2085. - Оп. 1. Д. 14. -221 л.

15. Пятилетний план восстановления и развития материально-транспортной базы по Автотресту НКАТ РСФСР Сталинградской области Сталинградской области на 1946-1950 годы // ГАВО. Ф. 2085.- Оп. 1.-Д. 14. - 170 л.

16. Развитие учреждений здравоохранения на 1943-1947 годы // ГАВО. - Ф. 686. - Оп. 20. Д. 5. -152 л.

17. Распределение денежных доходов в колхозах области за 1941-1946 годы // ГАВО. -Ф. 2085. Оп. 6. - Д. 13. - 19 л.

18. Репницкий, И. А. Демографическая ситуация в России в годы Великой Отечественной войны. 1941-1945 гг. // Известия Самарского научного центра Российской академии наук. - 2005. - Т. 7. № 2. - C. 279-288.

19. Сеть народного образования на 19431947 годы // ГАВО. - Ф. 686. - Оп. 20. - Д. 5. - 152 л.

20. Сравнительные данные об урожайности и валовом сборе сельскохозяйственных культур по данным годовых отчетов за 1941-1946 годы // ГАВО. Ф. 2085. - Оп. 6. - Д. 13. - 19 л.

21. Сравнительные данные о животноводстве в колхозах области за 1941-1946 годы // ГАВО. Ф. 2085. -Оп. 6. - Д. 13. - 19 л.

22. Ущерб государственным учреждениям и промышленности местного подчинения // ГАВО. Ф. 2115. - Оп. 1. - Д. 992. - 211 л.

\section{REFERENCES}

1. Analiz raspredeleniya valovogo sbora zernovykh i bobovykh kultur v kolkhozakh oblasti za 1941-1946 gody [The Analysis of Distribution of Gross Harvest of Grain and Leguminous Crops in Collective Farms of the Region in 1941-1946]. Gosudarstvennyy arkhiv Volgogradskoy oblasti [State Archive of the Volgograd Region], F. 2085, Op. 6, D. 13. 191.

2. Valovaya produktsiya $v$ neizmennykh tsenakh po predpriyatiyam soyuznoy i respublikanskoy 
promyshlennosti Stalingradskoy oblasti za 19431947 gody [Gross Production in Constant Prices of Enterprises of the Union and Republican Industries in the Stalingrad Region for 1943-1947]. Gosudarstvennyy arkhiv Volgogradskoy oblasti [State Archive of the Volgograd Region], F. 686, Op. 20, D. 5.1521 .

3. Valovaya produktsiya $\mathrm{v}$ naturalnom vyrazhenii [Gross Production in Physical Terms]. Gosudarstvennyy arkhiv Volgogradskoy oblasti [State Archive of the Volgograd Region], F. 2085, Op. 1, D. 4.1741 .

4. Vypusk glavnykh vidov produktsii soyuznoy i respublikanskoy promyshlennosti Stalingradskoy oblasti za 1943-1947 gody [Release of Key Types of Products of the Union and Republican Industries in the Stalingrad Region in 1943-1947]. Gosudarstvennyy arkhiv Volgogradskoy oblasti [State Archive of the Volgograd Region], F. 686, Op. 20, D. 5. 1521.

5. Gladkov I.A. Sovetskaya ekonomika v period Velikoy Otechestvennoy voyny 1941-1945 gg. [The Soviet Economy in the Period of the Great Patriotic War, 1941-1945]. Moscow, Nauka Publ., 1970. 505 p.

6. Doklad predsedatelyu SNK RSFSR Kosyginu ot 10 dekabrya 1943 goda [Report to the Chairman of the Council of People's Comissars of the RSFSR to Kosygin of December 10, 1943]. Gosudarstvennyy arkhiv Volgogradskoy oblasti [State Archive of the Volgograd Region], F. 2115, Op. 1, D. 989. 2111.

7. Materialy po vosstanovleniyu linii StalingradTikhoretskaya. 1943 g. [Materials on the Restoration of the Stalingrad-Tikhoretsk Line. 1943]. RGANTD [Branch of Russian State Archive for Scientific and Technical Documentation], F. R-129, Op. 5-1, D. 166. 881.

8. Mekhanizatsiya selskogo khozyaystva Stalingradskoy oblasti na period 1944-1947 godov [Mechanization of Agriculture in the Stalingrad Region for the Period 1944-1947]. Gosudarstvennyy arkhiv Volgogradskoy oblasti [State Archive of the Volgograd Region], F. 686, Op. 20, D. 5. 1111.

9. O razmere trudodnya kolkhoznikov (naturoy) za 1941-1946 gody [About the Size of Farmers' Workday (in-kind) for 1941-1946]. Gosudarstvennyy arkhiv Volgogradskoy oblasti [State Archive of the Volgograd region], F. 2085, Op. 6, D. 13. 191.

10. O trudovoy distsipline kolkhoznikov za 19411946 gody [On Labour Discipline of Farmers for 19411946]. Gosudarstvennyy arkhiv Volgogradskoy oblasti [State Archive of the Volgograd Region], F. 2085, Op. 6, D. 13. 191.

11. Planirovanie razmeshcheniya proizvoditelnykh sil SSSR: $v 2$ ch. Ch. 1 [Planning the Distribution of Productive Forces of the USSR: in 2 Parts. Part 1]. Moscow, Ekonomika Publ., 1985.304 p.

12. Posevnye ploshchadi po rayonam Stalingradskoy oblasti za 1940-1943 gody [Acreage by Districts of the Stalingrad Region for 1940-1943]. Gosudarstvennyy arkhiv Volgogradskoy oblasti [State Archive of the Volgograd Region], F. 2085, Op. 1, D. 25. 1391 .

13. Potrebnost rabochey sily dlya promyshlennykh predpriyatiy goroda Stalingrada na 1943-1947 gody [Need for Labour for Industrial Enterprises of Stalingrad in 1943-1947]. Gosudarstvennyy arkhiv Volgogradskoy oblasti [State Archive of the Volgograd Region], F. 686, Op. 20, D. 5.811.

14. Pyatiletniy plan vosstanovleniya i razvitiya dorozhnogo khozyaystva Stalingradskoy oblasti na 1946-1950 gody [The Five-Year Plan of Restoration and Development of the Road Sector in the Stalingrad Region in 1946-1950]. Gosudarstvennyy arkhiv Volgogradskoy oblasti [State Archive of the Volgograd region], F. 2085, Op. 1, D. 14. 2211.

15. Pyatiletniy plan vosstanovleniya i razvitiya materialno-transportnoy bazy po Avtotrestu NKAT RSFSR Stalingradskoy oblasti Stalingradskoy oblasti na 1946-1950 gody [The Five-Year Plan of Restoration and Development of Material and Transportation Base at Auto Company Group of NKAT RSFSR in the Stalingrad Region in 1946-1950]. Gosudarstvennyy arkhiv Volgogradskoy oblasti [State Archive of the Volgograd Region], F. 2085, Op. 1, D. 14. 1701.

16. Razvitie uchrezhdeniy zdravookhraneniya na 1943-1947 gody [The Development of Health Care Facilities in 1943-1947]. Gosudarstvennyy arkhiv Volgogradskoy oblasti [State Archive of the Volgograd Region], F. 686, Op. 20, D. 5. 1521.

17. Raspredelenie denezhnykh dokhodov $\mathrm{v}$ kolkhozakh oblasti za 1941-1946 gody [The Distribution of Cash Incomes at the Collective Farms of the Region in 1941-1946]. Gosudarstvennyy arkhiv Volgogradskoy oblasti [State Archive of the Volgograd Region], F. 2085, Op. 6, D. 13. 191.

18. Repnitskiy I.A. Demograficheskaya situatsiya v Rossii v gody Velikoy Otechestvennoy voyny. 19411945 gg. [The Demographic Situation in Russia During the Great Patriotic War. 1941-1945]. Izvestiya Samarskogo nauchnogo tsentra Rossiyskoy akademii nauk, 2005, vol. 7, no. 2, pp. 279-288.

19. Set narodnogo obrazovaniya na $1943-$ 1947 gody [The Network of Public Education in 19431947]. Gosudarstvennyy arkhiv Volgogradskoy oblasti [State Archive of the Volgograd Region], F. 686, Op. 20, D. 5.1521.

20. Sravnitelnye dannye ob urozhaynosti i valovom sbore selskokhozyaystvennykh kultur po dannym godovykh otchetov za 1941-1946 gody [Comparative Data on Yield and Gross Harvest of Agricultural Crops According to the Annual Reports for 1941-1946]. Gosudarstvennyy arkhiv Volgogradskoy oblasti [State Archive of the Volgograd Region], F. 2085, Op. 6, D. 13. 191. 
В.А. Аляев, М.В. Аляев. Отраслевые и территориальные изменения в хозяйстве Сталинградской области

21. Sravnitelnye dannye o zhivotnovodstve $\mathrm{v}$ kolkhozakh oblasti za 1941-1946 gody [Comparative Data on Livestocka at Collective Farms in the Region in 1941-1946]. Gosudarstvennyy arkhiv Volgogradskoy oblasti [State Archive of the Volgograd region], F. 2085, Op. 6, D. 13. 191.
22. Ushcherb gosudarstvennym uchrezhdeniyam i promyshlennosti mestnogo podchineniya [Damage to State Agencies and to the Industry of Local Subordinated Authorities]. Gosudarstvennyy arkhiv Volgogradskoy oblasti [State Archive of the Volgograd Region], F. 2115, Op. 1, D. 992. 211 1.

\section{Information About the Authors}

Vladimir A. Alyaev, Candidate of Sciences (Geography), Associate Professor, Department of Geography and Cartography, Volgograd State University, Prosp. Universitetsky, 100, 400062 Volgograd, Russian Federation, valyaev2004@mail.ru. https://orcid.org/0000-0003-3742-9444

Mikhail V. Alyaev, Candidate of Sciences (History), Associate Professor, Dean, Volgograd Cooperative Institute - Branch of Russian University of Cooperation, Novosibirskaya St., 76, 400002 Volgograd, Russian Federation, vfmupk04@yandex.ru. https://orcid.org/0000-0003-3732-2487

\section{Информация об авторах}

Владимир Алексеевич Аляев, кандидат географических наук, доцент кафедры географии и картографии, Волгоградский государственный университет, просп. Университетский, 100, 400062 г. Волгоград, Российская Федерация, valyaev2004@mail.ru, https:/orcid.org/0000-0003-3742-9444

Михаил Владимирович Аляев, кандидат исторических наук, доцент, декан, Волгоградский кооперативный институт (филиал) Российского университета кооперации, ул. Новосибирская, 76, 400002 г. Волгоград, Российская Федерация, vfmupk04@yandex.ru, https://orcid.org/0000-0003-3732-2487 